\title{
Turnaround Strategy Using Altman Model as a Tool in Solar Water Heater Industry in Karnataka
}

\author{
Mr. Y. M. Satish (Corresponding author) \\ Department of Management Studies, M.S. Ramaiah Institute of Technology \\ Vidya Soudha, MSRIT Post, MSR Nagar Bangalore. P O Box No. 560054, Karnataka state, India \\ Tel: 91-80-2360-0822 E-mail: ymsatish@yahoo.com
}

B. Janakiram

Professor and Head of the Department of Management Studies, M.S.Ramaiah Institute of Technology

Vidya Soudha, MSRIT Post, MSR Nagar Bangalore. P O Box No. 560054, Karnataka state, India

Tel: 91-80-2360-0822Ｅ-mail: drbjanakiram@hotmail.com

\begin{abstract}
The sale of goods on credit is an essential part of the modern competitive economic systems. The credit sales are generally made on open account, in the sense that, there are no formal acknowledgements of debt obligations through a financial instrument. As a marketing tool they are intended to promote sales and there by profits. However, extension of credit involves risk and cost. It is easy for the organization to provide credit sale but collecting amount from customers is difficult. If there is no proper credit evaluation, default rate will increase. This paper analyses whether Altman Z score model can predict correctly, the failure of customers.

The study is based on sample of 50 customers of M/s. Nuetech, during the period 2006-09. This study shows that Altman model performs well in predicting failures. The empirical results are interesting since they can be used by the organization in selecting the customers and assess their credit worthiness.
\end{abstract}

Keywords: Z Score, Credit worthiness, Bankruptcy, Credit scoring model, Multiple discriminate analysis

\section{Introduction}

In the competitive business environment, sale of goods on credit is inevitable. Accounts receivables are created by a firm when it sells its output on credit. The size of accounts receivables in the balance sheet of a firm depends on its credit policy.

Mian and Clifford (1992) pointed out that even in an advanced economy like the United States, accounts receivables constitute more than 20 per cent of the total assets of manufacturing firms

Centre for monitoring Indian economy (CMIE) statistics indicates that in India accounts receivables constitute more than 26 per cent of the total assets of manufacturing firms.

The Indian private corporate sector has not done well in the management of accounts receivable. The incidence of bad debt losses is quiet high. This is due to improper evaluation of the credit worthiness of their customers. An appropriate use of a suitable credit scoring model helps them in their credit granting decisions and thereby reduces bad debt losses. Credit scoring model can be used by the firms as a tool in effective turnaround of their businesses.

\section{Review of Literature}

\section{Historical Perspective of Credit Scoring Models}

Before the Second World War, models used for taking credit decisions were predominantly subjective. These models were highly individualistic as they depended on the experience and "hind-sights" of a particular credit manager. These subjective decision models had been very successful in the credit department of corporates and banks. The era produced brilliant credit managers and loan officers whose "rules of thumb" served them very well.

But after the Second World War, when the volume of business soared up, the subjective models failed to cope up with the increased volume because of dearth of experienced credit managers down the line. Their experience also 
could not be handed down effectively to the next line of managers because a large part of the credit decisions was instinctive.

The subjective process, while in many cases sufficient to do an acceptable job, also failed in that, it did not lend itself to administrative control (.Hettenhouse W. George and Jack R. Wentworth)

During the post second world war period, statistical analysis entered into the domain of credit scoring. First approach was probably made by David Durand.

With the advent of computer applications for business decisions there had been substantial development in credit scoring models but with mixed success.

Most unsuccessful application appeared to have failed because of a general lack of credibility or because of their use as a black box that supplanted human judgment (Hettenhouse W. George)

The credibility question is still valid today. Even in a country like the United States, many firms are not found to use a credit scoring model because of the general perception that such models are not sufficiently accurate. One of the reasons behind this is that most credit scoring models including the ones using option-pricing methodology were derived not from the experience with commercial credit defaults, rather from experience with the defaults in public bond markets. Even the empirical validation of these models could not be done in most cases, including banks, because of lack of appropriate database (McAllister H. Patrick and John J. Mingo). This is more true for statistical models where credit history and sample size must be sufficiently large to accommodate both analysis and verification.

Credit scoring models hitherto developed are mostly based on dichotomous classification tests- good credit and bad credit. These models are unable to accommodate shades of difference in loan quality. For example, some slow-paying customers are forced into one category or the other, but in truest sense, they belong somewhere between the two extremes.

Credit-scoring model based on financial ratios was systematically presented first by beaver by using sophisticated statistical techniques. He made a study of large firms of the United States dividing his sample between 79 failing companies and 79 successful companies, for the period 1954-64 by using univariate discriminant analysis. He found that some ratios predicted failure up to five years in advance and of which cash flow to total debt ratio (a close variation of debt-service coverage ratio) was the best predictor

Altman I. Edward (1968) took the research further and used multiple discriminant analysis (MDA) to develop " $\mathrm{Z}$ score" that might correctly classify firms which would fail within one year, 95 percent of the time of the initial sample and 79 percent of the time for the validation sample with an expected chance prediction of 50 percent. This, on the other hand, meant that the function derived by Altman had the ability to classify 8 out of 10 firms correctly as compared to 5 out of 10 firms which would have been correctly classified by chance.

Jonah Aiyabei (2002) discussed the theoretical aspect of a financially distressed firm based on a cyclical concept and examined the financial performance of small business firms based in Kenya using $\mathrm{Z}$ score model.

Ben McClure (2004) had confirmed the ' $Z$ ' score model through his research study and he concluded that to keep an eye on their investments, investors should consider checking their companies' Z-score on a regular basis. A deteriorating Z-score can signal trouble ahead and provide a simpler conclusion than the mass of ratios. Given its shortcomings, the $\mathrm{Z}$ is probably better used as a gauge of relative financial health rather than as a predictor. Arguably, it is best to use the model as a quick check of financial health, but if the score indicates a problem, it's a good idea to conduct a more detailed analysis.

In Indian context, L.C.Gupta (1999) attempted a refinement of Beaver's method with objective of predicting the business failure. Whereas, Mansur A Mulla (2002) made a study in Textile mill with the help of Z score model for evaluating the financial health with five weighted financial ratios and followed by Selvam M, and others (2004) had revealed about cements Industry's financial health especially India Cements Ltd. Krishna Chaitanya (2005) used Z model to measure the financial distress of Industrial Development Bank of India (IDBI) and concluded that IDBI is likely to become insolvent in the years to come.

\section{Theoretical framework}

Many potential lenders use credit scoring models to assess the credit worthiness of prospective borrowers. The credit worthiness of a customer will depend on many factors that may interact with each other. The technique of multiple discriminant analysis combines many factors according to importance (weight) to be given to each factor and it determines a composite score to differentiate good customers from bad customers. 
Edward Altman has developed a ' $Z$ ' Score model using financial statement ratios and multiple discriminate analyses to predict bankruptcy for publicly traded manufacturing firms. The specification of this model is given in table 1.

$$
\begin{aligned}
& Z=0.012 X_{1}+0.014 X_{2}+0.033 X_{3}+0.006 X_{4}+0.999 X_{5} \\
& \text { Where } \\
& \mathrm{X}_{1}=\text { working capital to total assets } \\
& \mathrm{X}_{2}=\text { retained earnings to total assets } \\
& \mathrm{X}_{3}=\text { earnings before interest and tax to total assets } \\
& \mathrm{X}_{4}=\text { market value of equity to book value of total liabilities } \\
& \mathrm{X}_{5}=\text { sales to total asset } \\
& \mathrm{Z}=\text { overall index }
\end{aligned}
$$

\section{'Z' Score components}

The $\mathrm{Z}$ score is calculated by multiplying the following accounting ratios, which is efficient in predicting bankruptcy.

1. $\mathrm{X}_{1}$ (Working Capital/Total Assets): This ratio expresses of the liquidity position of the company towards the total capitalization. Working capital is defined as the difference between current assets and current liabilities. Liquidity and size characteristics are explicitly considered.

2. $\mathrm{X}_{2}$ (Retained Earning/Total Assets): It indicates the amount reinvested, the earnings or losses, which reflects the extents of company's leverage. In other words, the extent to assets, which have been paid for by company profits. Those firms with high RE relative to TA have retention of profits and have not utilized as much debt. It also highlights either the use of internally generated finds for growth (low risk capital) Vs OPM (other people's money)-high risk capital. This is measure of cumulative profitability overtime and leverage as well.

3. $\mathrm{X}_{3}$ (EBIT/Total Assets): it is the measure of the company's operating performance and also it indicates the earning power of the company. In addition, this is a measure of the productivity of the firm's assets, independent of any tax or leverage factors. Since, a firm's ultimate existence is based on the earning power of its assets; this ratio appears to be particularly appropriate for studies dealing with credit risk.

4. $\mathrm{X}_{4}$ (Market Value of Equity/Book Value of Total Liabilities): it is the measure of the long term solvency of a company. It is reciprocal of the familiar debt-equity ratio. Equity is measured by the combined market value of all shares. While debt includes both current and long term liabilities. This measure shows how much assets of an enterprise can decline in value before the liabilities exceed the assets and the concern becomes insolvent.

5. $\quad \mathrm{X}_{5}$ (Sales/Total Assets): This is a standard turnover measure. Unfortunately, it varies greatly from one industry to another. In addition to this, it will reveal the sale generating capacity of the company's assets and also measure of management's capacity to deal with competitive conditions.

This paper analyses whether Altman Z-score model, can determine the credit worthiness of customers. In this study it is investigated whether Z-score models can predict bankruptcies for a period up to three years, and the correlation between Z-Score and its components.

\section{Objectives of the study}

- To analyze customer's creditworthiness by applying Z score model.

- To analyze the relationship between $\mathrm{Z}$ score value and its components.

This study analyses the status of customers of $\mathrm{M} / \mathrm{s}$. Nuetech in terms of their credit worthiness by calculating Z-scores using the financial data obtained through structured questionnaire and categorizes them as Bankrupt, Cannot say and Healthy using Altman Guidelines given in table 1. This helps the organization in identifying the right customers to deal with and granting sales credit.

The study also analyses the extent of correlation between financial variables and Z-Score which helps the organization in identifying significant financial variables to be considered in their credit granting decision. 
The effectiveness of Altman Model in predicting creditworthiness and the relationship between sales performance and creditworthiness in solar water industry in Karnataka is determined by formulating the following hypotheses:

1. Null Hypothesis $\left(\mathrm{H}_{0}\right)$ : Most of the customers are in healthy condition

2. Null Hypothesis $\left(\mathrm{H}_{0}\right)$ : The relationship between sales performance and creditworthiness is not significant

The hypothesis 1 is tested using Z-test as the sample size is large, the results of the test are given in page No. 14. The hypothesis 2 is tested using correlation analysis, the results of the test are given in Table No. 2.

\section{Participants, Measures and Methodology}

\subsection{Participants}

NSSPL is a Private Ltd Company situated at Bangalore, Karnataka, India. The company was established in the year 1988 as a partnership firm by 4 entrepreneurs for producing portable energy efficient cooking stoves. It became Private Ltd Company in the year 1992. It started manufacturing solar systems in the year 1992 and subsequently developed innumerable types of standard range of Solar systems. Today, it is having sales turnover of Rs 25 million. The company has many dealers spread across various states of India.

The data collection for the research was undertaken from both Primary and Secondary Sources. Primary data was collected by survey method using structured questionnaire and Secondary data was collected from various Journals, Magazines and News-papers.

Sample was drawn from a population of dealers of the company operating in the city of Bangalore, Karnataka, India. As per the records of the company there are 200 dealers operating in Bangalore, Karnataka. The sample size was calculated and the number of dealers to be contacted for data collection was 50 which is more than $20 \%$ of the total population. The 50 dealers were selected through Simple Random Sampling method using random table.

In the study of creditworthiness of customers, the respondents include $80 \%$ sole traders, $20 \%$ partnership firms who are dealers of Nuetech. $80 \%$ of the customers have 2-10 years experience in the same line of business and $20 \%$ are having less than 2 years of experience.

\subsection{Measures}

The data required for analyzing creditworthiness of customers was collected for 3 years i.e., April 2006 to April 2009. The customers are rated as Bankrupt, Cannot Say and Healthy on the basis of Z-Score values.

The questionnaire used for collecting data was pre-tested by administering it to a sample of 25 customers to check its construct validity. The construct validity was tested using Cronbach's alpha test. The result of the test showed that some of the questions had Cronbach coefficient alpha less than 0.70 and those questions were removed from the questionnaire.

\subsection{Methodology}

The collected data was processed by applying Z-Test and Correlation. Z-Test was applied for testing the effectiveness of Altman Z-Score model in predicting the creditworthiness of customers. Correlation of Z-Score components and Z-Score was determined to identify the degree of relationship between sales performance and creditworthiness.

\section{Results}

\subsection{Credit worthiness of customers and Altman Z-Score}

The credit worthiness of customers is depicted in Table -3 . There are three categories of customers namely: 1 . Bankrupt $(Z<1.81), 2$. Cannot say $(Z>1.81<2.99)$, 3. Healthy $(Z>2.99)$. The table indicates that most of the customers are in healthy condition as their $\mathrm{Z}$ score is more than 2.99 .

The $\mathrm{Z}$ test was performed on the above sample to test the effectiveness of Altman score in determining the credit worthiness of customers. The test also proved that most of the customers are in healthy condition by accepting the Null Hypothesis 1. The test results are given in page No. 14.

\subsection{Change in the status of Customers from 2006-2009}

The improvement in Altman Z score shows improvement in the status of customer's credit worthiness and vice versa. During the last three years the percentage of Healthy Customers has increased from $58 \%$ to $60 \%$, the 
percentage of customers who are Bankrupt is increasing consistently from $20 \%-24 \%$ and the percentage of customers of category Cannot Say has declined from $22 \%-16 \%$ as indicated by their $\mathrm{Z}$ scores during the period.

\subsection{Correlation between Sales performance and creditworthiness}

Correlation analysis done in the present research as shown in Table. 2, indicates the impact of sales performance in terms of Sales / Total assets ratio on credit worthiness of customers as reflected in Altman Z scores. The results show that there is a significant correlation between sales performance and credit worthiness as the coefficient of correlation is almost 1 (Perfectly positive). The Null Hypothesis 2 is rejected which implies that the relationship between sales performance and credit worthiness is not significant.

\section{Discussions}

- There is significant fluctuation in the status of customer's creditworthiness. Though majority of the customers are in healthy condition, the percentage of bankrupt customers are also increasing as indicated by the Altman Z score. Hence Nuetech should avoid the credit sales to the customers who are on the verge of bankruptcy. Before providing credit sale, company should assess the creditworthiness of the customers and if customers are creditworthy or in healthy condition, provide credit sale. This helps in turnaround of their sales performance.

- $\quad$ As there is a high degree of correlation between creditworthiness and sales to total assets ratio. It can be considered as one of the important factor in evaluating customers' creditworthiness.

- It should have different credit policies for different categories of customers and should reduce the credit period for those customers who are in "bankrupt" or "cannot say" condition.

- For assessing creditworthiness, some qualitative factors should also be considered. For example, business experience, market position of customers etc

\section{Limitations and Future Research}

- The present research is concerned with the study of creditworthiness of customers using Altman Z-Score Model in a Solar Water Industry. As such there are many areas for improvement and for further research. In particular we recognize that our study is subject to some important limitations. The first and most obvious limitation of the present study is limited by cost and time. Second limitation concerns the suggestions made by the study may require policy decisions and top management support for implementation. The findings from the current study have important implications on application of Altman Z-Score Model in evaluating the creditworthiness of customers in different sectors such as General Engineering, Electrical and Electronics, Printing and Stationery and other manufacturing sectors where the incidence of bad debt losses is a common phenomenon.

The early prediction of customer creditworthiness and designing appropriate credit policy decisions would help in the turn-around of many Small, Medium and Large Companies

\section{Implications and Conclusions}

In this study, the major findings are related to application of Altman credit score model to assess the creditworthiness of customers and to determine which ratio is most significant for Altman model. Apart from quantitative factors, some qualitative factors such as Character, Capacity, Capital and Condition of customers should also be considered in assessment of creditworthiness. This study also indicates that company should introduce assessment of creditworthiness before providing credit sales and changes should be made in the present credit policy.

\section{References}

Altman, E.I. (1968). Financial Ratios, Discriminant Analysis, and Prediction of corporate Bankruptcy. Journal of Finance, September, pp 589-609.

Beaver H.W. (1967). Financial Ratios as Predictors of Failure. Empherical Research in Accounting, Selected Studies, University of Chicago.

Ben McClure. (2004). Z Marks The End. February 11, [Online] Available: www.investopedia.com

Bhattacharya, Hrishikes. Total Management by Ratios - An Integrated Approach. Sage Publications, pp 243-248

Bhattacharya, Hrishikesh. (2005). Working Capital Management: Strategies and Techniques. $1^{\text {st }}$ Edition, Prentice-Hall of India, pp 98-102 
Chandra Prasanna. (2008). Financial Management: Theory and Practice. 7th Edition, Tata Mc-Graw Hill publications, pp 1012-1015.

Charley Kyd. (2005). Predict business bankruptcy using Z score with excel. August, [Online] Available: www.solvency.com

Durand David. (1941). Risk Elements in Consumer Installment Lending. National Bureau of Economic Research, Washington.

Gupta, L.C. (1999). Financial Ratios as Forewarning Indicators of Corporate Sickness. Bombay. ICICI

Hettenhouse W. George and Jack R. Wentworth. (1971). A New Look For Credit Scoring. The Journal of Commercial Bank Lending, September, 1971, pp 26-32.

Jonah Aiyabei. (2002). Financial Distress: Theory, Measurement and consequence. The Eastern Africa Journal of Humanities and Sciences, Vol.1, No. 1.

Krishna Chaitanya V. (2005). Measuring Financial Distress of IDBI Using Altman Z-Score Model. The ICFAI Journal of Bank Management, August, Vol.IV, No.3, pp 7-17

Mansur.A Mulla. (2002). Use of Z score analysis for Evaluation of financial health of Textile Mills-A case study. Abhigyan, Jan-March, Vol.XIX, No.4, pp 37-41

Mc Allister H Patrick and John J. Mingo. (1994). Commercial Loan Risk Management: Credit Scoring and Pricing; The Need for a New Shared Database. The Journal of Commercial Lending, May, pp 6-22.

Pandey, I.M. (2005). Financial Management, $9^{\text {th }}$ Edition, Delhi, Vikas Publishing House Ltd., Chapter-25.

Selvam, M., Vanitha. S., \& Babu. (2004). A Study of financial health of cement industry-“Z score analysis". The Management Accountant, July, Vol.39, No.7, pp 591-593.

Table 1. Altman Guidelines

\begin{tabular}{l|l}
\hline Predictive status & "Z" score \\
\hline Bankrupt & 1.81 or less \\
\hline Cannot say & $1.81-2.99$ \\
\hline Healthy & More than 2.99 \\
\hline
\end{tabular}

Table 2. 'Z' Score Components and Their Correlation with Z Score

\begin{tabular}{c|c|c|c|c|c|c|c}
\hline $\begin{array}{c}\text { Financial } \\
\text { ratios }\end{array}$ & $\mathbf{2 0 0 6 - 0 7}$ & $\begin{array}{c}\text { Correlation } \\
\text { with Z } \\
\text { Scores }\end{array}$ & $\mathbf{2 0 0 7 - 0 8}$ & $\begin{array}{c}\text { Correlation } \\
\text { with Z } \\
\text { Scores }\end{array}$ & $\mathbf{2 0 0 8 - 0 9}$ & $\begin{array}{c}\text { Correlation } \\
\text { with Z } \\
\text { Scores }\end{array}$ & Remarks \\
\hline $\begin{array}{c}\text { Working } \\
\text { capital/Total } \\
\text { Assets }\end{array}$ & 27.027 & 0.453181441 & 29.46221 & 0.4945207 & 29.74715 & 0.4278157 & $\begin{array}{c}\text { Not } \\
\text { significant }\end{array}$ \\
\hline $\begin{array}{c}\text { Retained } \\
\text { Earnings/Total } \\
\text { Assets }\end{array}$ & 18.64 & 0.581083167 & 18.853204 & 0.5818034 & 19.449809 & 0.4238845 & $\begin{array}{c}\text { Not that very } \\
\text { significant }\end{array}$ \\
\hline $\begin{array}{c}\text { EBIT/ Total } \\
\text { Assets }\end{array}$ & 26.6631 & 0.449733258 & 27.490649 & 0.4286411 & 25.831584 & 0.449892 & $\begin{array}{c}\text { Not that very } \\
\text { significant }\end{array}$ \\
\hline $\begin{array}{c}\text { Market value of } \\
\text { Equity/Book } \\
\text { value of total } \\
\text { Liability }\end{array}$ & 121.2857 & 0.120525069 & 108.62928 & 0.1638347 & 114.91154 & 0.2092167 & $\begin{array}{c}\text { Not at all } \\
\text { significant }\end{array}$ \\
\hline $\begin{array}{c}\text { Sales / Total } \\
\text { Assets }\end{array}$ & 158.611 & 0.999898974 & 163.97553 & 0.9999422 & 156.44332 & 0.9662222 & Highly \\
significant \\
\hline Z Score
\end{tabular}

Source: Field survey 
Table 3. 'Z' Score Values

\begin{tabular}{|c|c|c|c|c|c|c|c|c|c|}
\hline S.NO & 2006-07 & 2007-08 & 2008-09 & Remarks & S.NO & 2006-07 & 2007-08 & 2008-09 & Remarks \\
\hline 1 & 2.012 & 2.099917 & 3.3518 & $\begin{array}{c}\text { Cannot say to } \\
\text { Healthy }\end{array}$ & 26 & 5.2628 & 5.779143 & 6.731833 & Healthy \\
\hline 2 & 1.3596 & 1.281844 & 1.2259 & Bankrupt & 27 & 2.4306 & 2.181192 & 1.52416 & $\begin{array}{l}\text { Cannot say } \\
\text { to bankrupt }\end{array}$ \\
\hline 3 & 2.027 & 1.513667 & 1.3465 & $\begin{array}{c}\text { Cannot say to } \\
\text { bankrupt }\end{array}$ & 28 & 2.9087 & 3.148048 & 3.257 & $\begin{array}{l}\text { Cannot say } \\
\text { to Healthy }\end{array}$ \\
\hline 4 & 4.4462 & 4.4462 & 3.036667 & Healthy & 29 & 4.696 & 3.586833 & 3.36875 & Healthy \\
\hline 5 & 3.7761 & 4.032 & 4.201667 & Healthy & 30 & 5.0531 & 3.64688 & 2.53607 & $\begin{array}{l}\text { Healthy to } \\
\text { cannot say }\end{array}$ \\
\hline 6 & 3.5505 & 2.78935 & 3.369125 & Healthy & 31 & 4.4163 & 4.841528 & 5.0477 & Healthy \\
\hline 7 & 3.369167 & 3.03275 & 3.0353 & Healthy & 32 & 1.3427 & 1.47308 & 1.3151 & Bankrupt \\
\hline 8 & 4.0325 & 4.196175 & 4.54665 & Healthy & 33 & 4.0368 & 3.726964 & 3.03184 & Healthy \\
\hline 9 & 1.5196 & 3.7845 & 2.71386 & $\begin{array}{l}\text { bankrupt to } \\
\text { cannot say }\end{array}$ & 34 & 3.5501 & 4.061391 & 4.0699 & Healthy \\
\hline 10 & 3.3615 & 3.188071 & 3.0366 & Healthy & 35 & 5.039 & 5.760095 & 5.60968 & Healthy \\
\hline 11 & 3.4126 & 2.345429 & 4.0704 & Healthy & 36 & 0.7162 & 0.736895 & 0.68437 & Bankrupt \\
\hline 12 & 3.8553 & 6.417409 & 4.43598 & Healthy & 37 & 1.3446 & 1.26139 & 1.40832 & Bankrupt \\
\hline 13 & 4.0444 & 5.374567 & 4.03065 & Healthy & 38 & 1.6927 & 1.812398 & 1.69202 & Bankrupt \\
\hline 14 & 6.0855 & 4.56925 & 2.5321 & $\begin{array}{l}\text { Healthy to } \\
\text { cannot say }\end{array}$ & 39 & 5.0208 & 6.041433 & 4.02051 & Healthy \\
\hline 15 & 3.0157 & 2.297229 & 2.01145 & $\begin{array}{l}\text { Healthy to } \\
\text { cannot say }\end{array}$ & 40 & 2.4258 & 1.77223 & 1.5226 & $\begin{array}{l}\text { Cannot say } \\
\text { to bankrupt }\end{array}$ \\
\hline 16 & 5.103 & 5.242714 & 4.1636 & Healthy & 41 & 2.0166 & 1.776316 & 1.80428 & $\begin{array}{l}\text { Cannot say } \\
\text { to bankrupt }\end{array}$ \\
\hline 17 & 0.0429 & 0.03961 & 0.08724 & Bankrupt & 42 & 1.7703 & 1.967309 & 1.88783 & Bankrupt \\
\hline 18 & 0.2155 & 0.18396 & 0.3064 & Bankrupt & 43 & 1.525 & 1.619232 & 1.59004 & Bankrupt \\
\hline 19 & 1.896 & 1.696667 & 1.96992 & cannot say & 44 & 1.904 & 2.355046 & 2.47472 & cannot say \\
\hline 20 & 5.3523 & 6.696233 & 5.2427 & Healthy & 45 & 2.24 & 2.42745 & 2.10851 & cannot say \\
\hline 21 & 5.0638 & 5.0718 & 5.38573 & Healthy & 46 & 2.8832 & 2.849839 & 3.0295 & $\begin{array}{c}\text { cannot sat to } \\
\text { Healthy }\end{array}$ \\
\hline 22 & 7.04748 & 7.544083 & 6.85318 & Healthy & 47 & 3.3728 & 3.64344 & 3.11246 & Healthy \\
\hline 23 & 2.6588 & 2.289183 & 3.03845 & $\begin{array}{c}\text { Cannot say to } \\
\text { Healthy }\end{array}$ & 48 & 2.0399 & 2.6149 & 2.92225 & cannot say \\
\hline 24 & 2.3264 & 3.463686 & 3.78765 & $\begin{array}{c}\text { Cannot say to } \\
\text { Healthy }\end{array}$ & 49 & 4.055 & 4.169321 & 4.09906 & Healthy \\
\hline 25 & 5.0693 & 4.816034 & 4.9685 & Healthy & 50 & 4.3181 & 4.323333 & 4.03427 & Healthy \\
\hline
\end{tabular}

Source: Field survey 


\section{Results of ' $Z$ ' Test}

$\mathrm{H}_{0}$ : Most of the customers are in healthy condition.

$\mathrm{H}_{\mathrm{a}}$ : Most of the customers are not in healthy condition

$\mathrm{H}_{0}: \mu>1.7884$

$\mathrm{H}_{\mathrm{a}}: \mu \leq 1.7884$

It is a one time test (right side)

Sample mean $=\bar{X}=3.12562$

Standard deviation (S.D) $=1.548275$

$$
\begin{aligned}
& Z=\frac{\bar{X}-\mu}{S . D / \sqrt{N}} \\
& Z=\frac{3.12562-1.7884}{1.548275 / 7.071}
\end{aligned}
$$

$\mathrm{Z}=0.86372$

At $5 \%$ level of significance, $\mathrm{Za}=1.645$

So, $\mathrm{Z}$ value is less than 1.645 , Null Hypothesis is accepted.

In Nuetech, most of the customers are in healthy condition. 